\author{
MirosŁaW WójtowiCz \\ Uniwersytet Pedagogiczny w Krakowie, Polska \\ Pedagogical University of Krakow, Poland
}

\title{
Wpływ stabilizacii politycznej i gospodarczej na rozwój przemysłu samochodowego i motoryzacii w Kolumbii na początku XXI wieku
}

\author{
Impact of Political and Economic Stabilisation on the Development \\ of the Automotive Industry and Motorisation in Colombia at the Beginning \\ of the 21st Century
}

Streszczenie: Jeszcze w 2000 roku Kolumbia uznawana była za kraj wysoce niestabilny politycznie, w którym od dłuższego czasu trwał konflikt zbrojny między wojskiem a różnymi grupami partyzanckimi oraz handlarzami narkotyków. Utrudniało to rozwój gospodarczy, ograniczało rozwój przemysłu i negatywnie wpływało na zachowania konsumenckie ludności. Zapoczątkowane na początku XXI wieku rozmowy pokojowe doprowadziły do stopniowego ustabilizowania sytuacji wewnętrznej w kraju, co stało się impulsem do przyspieszenia rozwoju gospodarczego oraz poprawy nastrojów konsumenckich. Przemysł samochodowy był jednym z tych sektorów gospodarki, które zyskały zdecydowany impuls rozwojowy. Znalazło to swoje odzwierciedlenie we wzroście zatrudnienia oraz produkcji nowych samochodów, które w latach 2000-2017 znacząco wzrosły. Jeszcze dynamiczniej wzrosła sprzedaż nowych aut, co wiązało się ze wzrostem importu i pogorszeniem bilansu handlowego tego sektora. Głównym celem jest określenie wpływu stabilizacji politycznej i związanej z nią poprawy sytuacji gospodarczej w Kolumbii na rozwój przemysłu samochodowego napędzany wzrostem sprzedaży nowych pojazdów. Starano się również określić wpływ poziomu rozwoju gospodarczego i infrastruktury drogowej na regionalne zróżnicowanie sprzedaży nowych samochodów.

Abstract: As early as in 2000, Colombia was considered a highly politically unstable country in which a long-standing armed conflict between the army and various guerrilla groups and drug traffickers had been going on for a long time. These conditions hampered economic development, limited the development of industry and negatively affected consumer behaviour of inhabitants. The peace talks initiated at the beginning of the 21st century led to a gradual stabilisation of the internal situation in the country, which became an impulse for accelerating economic development and improving consumer moods. The automotive industry was one of those sectors of the economy that gained a strong development impulse. This was reflected in the increase in employment and production of new cars, which in the period 2000-2017 increased significantly. The sales of new cars grew even more dynamically which was associated with an increase in imports and a deterioration in the trade balance of this sector. The main objective of this study is to determine the impact of political stability and the associated improvement in the economic situation in Colombia on the development of the car industry driven by the growth in sales of new vehicles. Efforts were also made to determine 
the impact of the level of economic development and road infrastructure on the regional diversification of sales of new cars.

Słowa kluczowe: Kolumbia; motoryzacja; przemysł samochodowy; rozwój społeczno-gospodarczy Keywords: automotive industry; Colombia; motorisation; socio-economic development

Otrzymano: 13 stycznia 2019

Received: 13 January 2019

Zaakceptowano: 12 lipca 2019

Accepted: 12 July 2019

Sugerowana cytacja / Suggested citation:

Wójtowicz, M. (2019). Wpływ stabilizacji politycznej i gospodarczej na rozwój przemysłu samochodowego i motoryzacji w Kolumbii na początku XXI wieku. Prace Komisji Geografii Przemysłu Polskiego Towarzystwa Geograficznego, 33(4), 132-150. doi: 10.24917/20801653.334.8

\section{WSTĘP}

Konflikt wewnętrzny ma w Kolumbii długą tradycję, która sięga XIX wieku, kiedy to często przemoc, a nie demokratyczne wybory, legitymizowała władzę kolejnych rządów. Od połowy lat czterdziestych XX wieku silna polaryzacja polityczna i narastające antagonizmy pomiędzy dwoma głównymi partiami: liberałami i konserwatystami coraz bardziej dawały o sobie znać i przeradzały się w otwarty konflikt. Wybuchł on w całej pełni w 1948 roku po zabójstwie przywódcy liberałów Jorgego Eliécera Gaitána i trwał do połowy lat sześćdziesiątych XX wieku. W historii Kolumbii okres ten określa się mianem La Violencia (Safford, Palacios, 2002; Gawrycki, 2005; Deas, 2015). W tym czasie doszło do masowych ucieczek ludności z obszarów wiejskich do miast, co w konsekwencji przyczyniło się do gwałtownego wzrostu urbanizacji. Zwiększenie zasobów siły roboczej w głównych miastach sprzyjało natomiast przyspieszeniu industrializacji. Kolejnym impulsem przyspieszającym rozwój gospodarczy był wzrost cen kawy w pierwszej dekadzie po zakończeniu II wojny światowej. W latach 1945-1955 tempo wzrostu gospodarczego wynosiło 5\% średniorocznie. Duża część dochodów eksportowych została przeznaczona na inwestycje w kapitał stały, głównie import maszyn i wyposażenia fabryk (Ocampo, Tovar, 2000 ; Bértola, Ocampo, 2012).).

Od połowy lat sześćdziesiątych XX wieku w Kolumbii rozpoczyna się okres partyzanckiej guerrilli, który doprowadził do wybuchu permanentnej wojny domowej. Toczyła się ona z największą intensywnością na peryferyjnych obszarach kraju. Duże miasta i przylegające do nich gęściej zaludnione obszary pozostawały pod kontrolą wojsk rządowych. Wschodnie departamenty oraz tereny górskie były domeną działalności różnych grup partyzanckich oraz handlarzy narkotyków (Kowalewski, 1978; Gawrycki, 2005). Przyczyniało się to do pogłębienia i tak już bardzo wysokich dysproporcji przestrzennych w poziomie rozwoju gospodarczego oraz ekstremalnie wysokich nierówności w jego podziale (Fleet, 1984; Ocampo, Tovar, 2000; Bértola, Ocampo, 2012).).

Dopiero od czasów prezydentury Belisaria Betancura (1982-1986) rozpoczęły się próby politycznego rozwiązania tego kryzysu. Grupy partyzanckie przestano traktować jak wywrotowców, które trzeba militarnie zniszczyć, a podjęto próby negocjacji pokojowych. Były one kontynuowane przez kolejnych prezydentów, z mniejszymi bądź większymi sukcesami. Zawieszenie broni uzgodnione w trakcie prezydentury Andrésa Pastrany (1998-2002) w dłuższej perspektywie nie przyniosło jednak spodziewanego zakończenia konfliktu. Dopiero we wrześniu 2016 roku w trakcie drugiej kadencji 
rządów prezydenta Manuela Santosa (2010-2018) udało się podpisać porozumienie z główną grupą partyzancką FARC, kończące wojnę domową (Sapieżyńska, 2016; Stasiński, 2016).

Zainicjowane w okresie rządów A. Pastrany rozmowy pokojowe, zwieńczone porozumieniem z 2016 roku, to okres stopniowej stabilizacji politycznej i poprawy sytuacji gospodarczej. Zakończenie wojny domowej było ważnym bodźcem niosącym nowe nadzieje na długo wyczekiwany pokój oraz poprawę nastrojów zarówno w gospodarce, jak i wśród konsumentów. Poprawiało też notowania kraju wśród międzynarodowych inwestorów a osiągnięta po długim okresie stabilizacja polityczna niosła ze sobą obietnicę zysków dla potencjalnych inwestorów. Celem artykułu jest określenie, jak ustabilizowanie sytuacji politycznej i związana z nim poprawa sytuacji gospodarczej wpłynęły na rozwój przemysłu samochodowego i wzrost sprzedaży nowych aut w Kolumbii w pierwszych dekadach XXI wieku. Aby zrealizować główny cel pracy, podjęto próbę odpowiedzi na następujące pytania:

- Czy i w jakim stopniu wygaszanie konfliktu zbrojnego w Kolumbii wpłynęło na rozwój przemysłu samochodowego w tym kraju?

- Czy wraz z rozwojem gospodarczym wzrosła wielkość produkcji i sprzedaży nowych aut oraz jaką rolę odegrał import pojazdów z zagranicy?

- Jak rozkłada się przestrzennie sprzedaż samochodów i czy wykazuje ona korelację z poziomem rozwoju gospodarczego kolumbijskich departamentów?

- Czy wzrosło znaczenie przemysłu samochodowego dla kolumbijskiej gospodarki oraz lokalnego rynku motoryzacyjnego?

Tak przyjęty cel badań oraz pytania szczegółowe uwarunkowały układ pracy, w której kolejny podrozdział ma na celu zbadanie dynamiki rozwoju gospodarczego w Kolumbii w latach 2000-2017. W kolejnym podrozdziale zaprezentowano krótką historię rozwoju kolumbijskiego przemysłu samochodowego, aby przejść następnie do zbadania rozwoju tego sektora w latach 2000-2017. W dalszej części pracy zbadano zmiany popytu na nowe samochodowy oraz strukturę przestrzenną ich rejestracji, starając się określić, czy wykazuje on współzależność z poziomem rozwoju gospodarczego. W podsumowaniu próbowano odpowiedzieć na pytanie o rolę przemysłu samochodowego w gospodarce Kolumbii.

\section{ROZWÓJ GOSPODARCZY KOLUMBII W LATACH 2000-2017}

Od początku XXI wieku do wybuchu światowego kryzysu w 2008 roku gospodarka kolumbijska rozwijała się dynamicznie, a PKB wzrósł o blisko 41\% w porównaniu z 2000 rokiem. Kryzys gospodarczy doprowadził do spowolnienia tempa wzrostu PKB do 1,2\% w 2009 roku, jednakże miał krótkotrwały wpływ i już w kolejnym roku odnotowano wzrost o 4,3\%, a rekordową wartość - 7,4\% - w 2011 roku. W kolejnych latach tempo wzrostu zaczęło spowalniać, osiągając wartość 1,8\% w 2017 roku. Warto jednak podkreślić, iż w całym badanym okresie nie odnotowano spadku PKB, a jego wartość w 2017 roku była o 94\% wyższa w porównaniu do 2000 roku (rycina 1).

Podobnie ewoluowały wartości PKB per capita, jednakże ze względu na stosunkowo szybki przyrost ludności ich tempo wzrostu było znacznie niższe. W badanym okresie wartość PKB per capita zwiększyła się o blisko 60\% z poziomu 4765 dol. na osobę w 2000 roku do 7613 dolarów na osobę w 2017 roku (w cenach stałych z 2010 roku) (rycina 1). Odnotowany wzrost PKB per capita świadczy o znaczącej poprawie sytuacji 
Rycina 1. Dynamika (A) i wskaźniki średniorocznego wzrostu (B) PKB w latach 2000-2017 w cenach stałych z 2010 roku

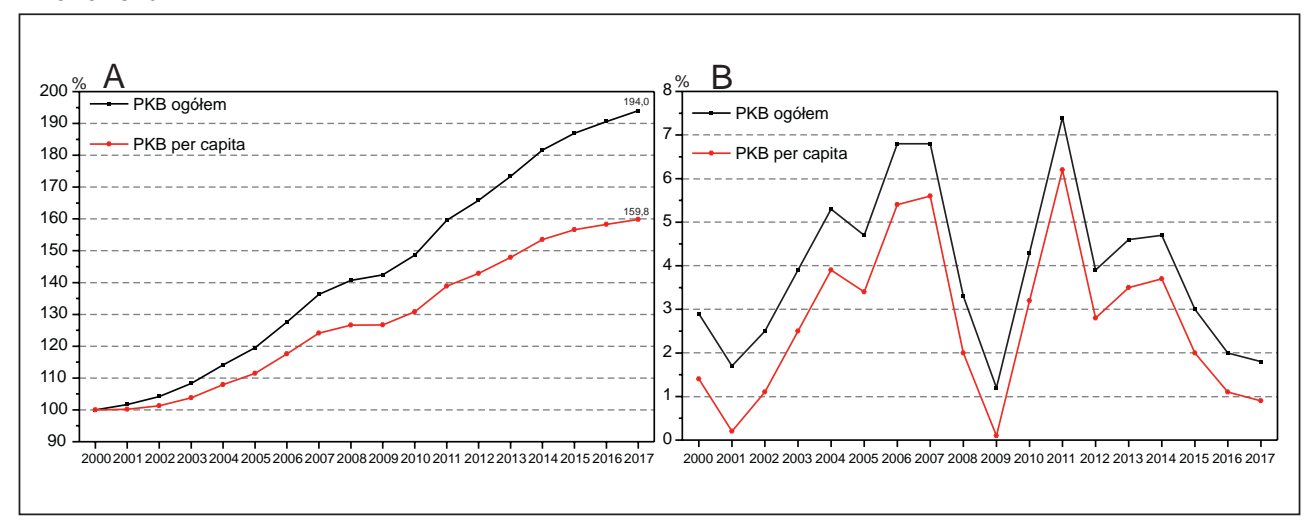

Źródło: opracowanie własne na podstawie danych CEPAL (2018)

gospodarczej w Kolumbii, co powinno znaleźć swoje potwierdzenie także we wzroście konsumpcji dóbr trwałych. Zostanie to w dalszej części zweryfikowane na przykładzie sprzedaży nowych samochodów.

\section{HISTORIA PRZEMYSŁU SAMOCHODOWEGO W KOLUMBII}

Zanim zostanie przedstawiona współczesna sytuacja sektora motoryzacyjnego w Kolumbii, warto w zarysie przedstawić historię jego rozwoju. Jego początki wiążą się z 1960 rokiem, kiedy to w Bogocie powstały najstarsze fabryki montujące samochody z importowanych części. Pierwsza z nich - Colomotores - początkowo produkowała auta osobowe i ciężarowe marki Austin, a następnie Chrysler. Druga - Leonidas Lara e Hijos - zajmowała się montażem dżipów marki Willys oraz ciężarówek International. Jednakże ich produkcja była nieregularna oraz stosunkowo niewielka i w 1967 roku wynosiła łącznie zaledwie 2631 sztuk (Michelsen, 1979; Fleet, 1984).

Większy nacisk na rozwój przemysłu samochodowego położono w okresie rządów Carlosa Llerasa (1966-1970). Realizowana wówczas strategia rozwoju łączyła dywersyfikację eksportu z jednoczesnym rozwojem rodzimego przemysłu. Biorąc pod uwagę niewielką chłonność lokalnego rynku, władze zdecydowały się ograniczyć liczbę firm produkujących samochody. Początkowo zakładano, że jedynie jeden producent będzie dostarczał małe samochody osobowe, co pozwoliłoby mu osiągnąć skalę zapewniającą opłacalność produkcji. Jednakże z czasem pozwolono na produkcję konkurencyjnych modeli także firmom Chrysler Colomotores i Leonidas Lara e Hijos, które już wcześniej rozpoczęły w tym kraju montaż większych pojazdów (Fleet, 1982; Jenkins, 1987).

Po kilku latach rozmów z koncernami międzynarodowymi w 1969 roku podpisano porozumienie z francuskim Renault. Koncern zgodził się utworzyć spółki join venture z rządem kolumbijskim, reprezentowanym przez Instytut Rozwoju Przemysłowego (Instituto de Fomento Industrial - IFI), zajmujące się produkcją małych samochodów osobowych oraz silników do nich. Produkcją samochodów zajmowała się spółka Sofasa, w której IFI miał 50\% udziałów, a zakład o zdolności produkcyjnej 15 tys. pojazdów rocznie zlokalizowano w Medellín. Produkcją silników zajmowała się spółka Socofam, w której IFI miał aż 70\% udziałów, a fabrykę o zdolności produkcyjnej 20 tys. sztuk 
rocznie zlokalizowano w mieście Duitama w departamencie Boyacá, leżącym około 200 km na północny wschód od Bogoty. Sprzedażą produkowanych samochodów na miejscowym rynku zajmowała się trzecia spółka - Renault de Colombia, w której IFI miał jedynie 30\% udziałów (Sandoval, Mick, Guterman, 1981; Fleet, 1982).

W 1970 roku wygasły licencje na montaż pojazdów wydane 10 lat wcześniej Chrysler Colomotores i Leonidas Lara e Hijos. W prowadzonych negocjacjach rząd oczekiwał od tych firm większego zaangażowania w rozwój przemysłu samochodowego oraz wykorzystania miejscowych części, które było wówczas na poziomie 19\%. W przypadku Chryslera negocjacje skończyły się pozostawieniem firmy w zagranicznych rękach, ale pozostała część nowej umowy była bardzo podobna do tej zawartej z Renault. Jedną zasadniczą różnicą była rezygnacja z konieczności budowy fabryki silników. Zamiast tego Chrysler zgodził się zainwestować $10 \mathrm{mln}$ dol. w ciągu następnych 10 lat w rozwój produkcji części samochodowych w Kolumbii. Początkowo firma Leonidas Lara e Hijos mogła liczyć na specjalne traktowanie, jednakże w 1972 roku zmuszono ją do połączenia się z IFI oraz Fiatem i utworzenia spółki Compaña Colombiana Automotriz (CCA). Miała się ona zająć produkcją samochodów osobowych i ciężarowych marki Fiat na podobnych zasadach, jakie uzgodniono wcześniej z Renault i Chryslerem. Dzięki tak prowadzonej polityce od lat siedemdziesiątych XX wieku na kolumbijskim rynku działały trzy koncerny produkujące samochody (Michelsen, 1979; Fleet, 1982).

Produkcja samochodów w latach siedemdziesiątych XX wieku wykazywała wysokie tempo wzrostu, osiągając poziom 48,7 tys. sztuk w 1979 roku. Na początku lat osiemdziesiątych XX wieku gospodarka kolumbijska odczuła skutki kryzysu zadłużeniowego, a spadek konsumpcji był szczególnie widoczny w przemyśle samochodowym. Produkcja aut spadła z poziomu 42727 sztuk w 1980 roku do 28149 w 1983 roku, by w 1984 roku wrócić do 45147 sztuk. Druga połowa lat osiemdziesiątych wiązała się z restrukturyzacją i modernizacją produkcji samochodów. Doszło także do znaczących zmian własnościowych, gdyż w 1979 roku Chrysler sprzedał swoje zakłady GM, natomiast w 1983 roku Fiat sprzedał CCA japońskiemu koncernowi Mazda. Liberalizacja handlu zagranicznego, a szczególnie redukcja ceł na samochody z 300\% do 75\% w latach 1990-1991 oraz wejście we wrześniu 1991 roku w życie porozumienia o zerowych stawkach celnych w handlu z Wenezuelą, stały się kolejnym impulsem zmuszającym do poprawy efektywności i zmniejszenia kosztów produkcji pojazdów. Wiązało się to z koniecznością modernizacji i mechanizacji istniejących zakładów, co w konsekwencji prowadziło do redukcji zatrudnienia (Cárdenas, 1998).

\section{KOLUMBIJSKI PRZEMYSŁ SAMOCHODOWY NA POCZĄTKU XXI WIEKU}

W pierwszych dekadach XXI wieku w Kolumbii funkcjonowało osiem fabryk zajmujących się montażem samochodów. Najdłuższe tradycje mają zakłady GM Colmotores oraz Sofasa Renault, związane z początkami rozwoju przemysłu samochodowego w tym kraju. Produkcją samochodów ciężarowych i lekkich użytkowych zajmują się natomiast: Hino Motors Manufacturing SA z grupy Toyoty oraz Fotón, będący filią chińskiego koncernu Beiqi Foton Motor, który w 2015 roku otworzył fabrykę w mieście Funza w departamencie Cundinamarca niedaleko Bogoty. Natomiast produkcją autobusów i busów zajmują się: Non Plus Ultra SA (montująca głównie busy marki Volkswagen), Compañía de Autoensamble Nissan (montująca samochody Nissan), Navistrans SA (brazylijska marka Agrale) oraz Daimler (montująca autobusy marki Mercedes Benz). 
Łączna zdolność produkcyjna powyższych fabryk wynosiła w 2014 roku 320 tys. pojazdów rocznie, natomiast w sektorze produkcji części samochodowych funkcjonowało 187 zakładów (Dorocki, 2010; ANDI, 2017).

Warto również wspomnieć, iż Kolumbia ma bardzo dobrze rozwiniętą produkcję motorów i motorowerów. Funkcjonuje sześć fabryk produkujących motory takich marek, jak m.in.: Suzuki, Honda, Yamaha, Bajaj, Kymco, Kawasaki, KTM. Łączna produkcja przekroczyła 533,5 tys. sztuk w 2016 roku. (ANDI, 2017). Kolumbia, podobnie jak inne państwa rozwijające się, jest bardzo atrakcyjnym rynkiem dla motocykli (Dorocki, 2018), a ich sprzedaż w ostatnich latach znacznie przewyższa sprzedaż samochodów (ANDI, 2017). Niemniej jednak w niniejszym artykule skupiono się jedynie na przemyśle samochodowym.

W 2014 roku przemysł ten zatrudniał było blisko 18,3 tys. pracowników, co stanowiło 2,66\% ogółu zatrudnionych w przemyśle przetwórczym w Kolumbii. W kolejnych latach zatrudnienie w tym sektorze zaczęło spadać, osiągając w 2017 roku poziom 15,5 tys. osób. W strukturze zatrudnienia w przemyśle samochodowym dominuje dział produkcji części samochodowych, skupiający w 2017 roku 7,9 tys. pracowników, czyli ponad dwukrotnie więcej niż w roku 2000. Jeszcze wyższą dynamikę zatrudnienia odnotowano w dziale produkcji karoserii, gdzie w latach 2000-2017 zwiększyło się ono o $114,3 \%$, z 2,1 do 4,5 tys. osób. Natomiast najmniejsze zmiany zaszły w dziale produkcji samochodów oraz silników, w którym, pomimo krótkookresowych wzrostów w roku 2007 i 2012, w skali całego badanego okresu pozostało ono praktycznie na tym samym poziomie (rycina 2).

Rycina 2. Zmiany wielkości i struktury zatrudnienia w przemyśle samochodowym oraz jego udziału w ogólnym zatrudnieniu przemysłowym w Kolumbii w latach 2000-2017

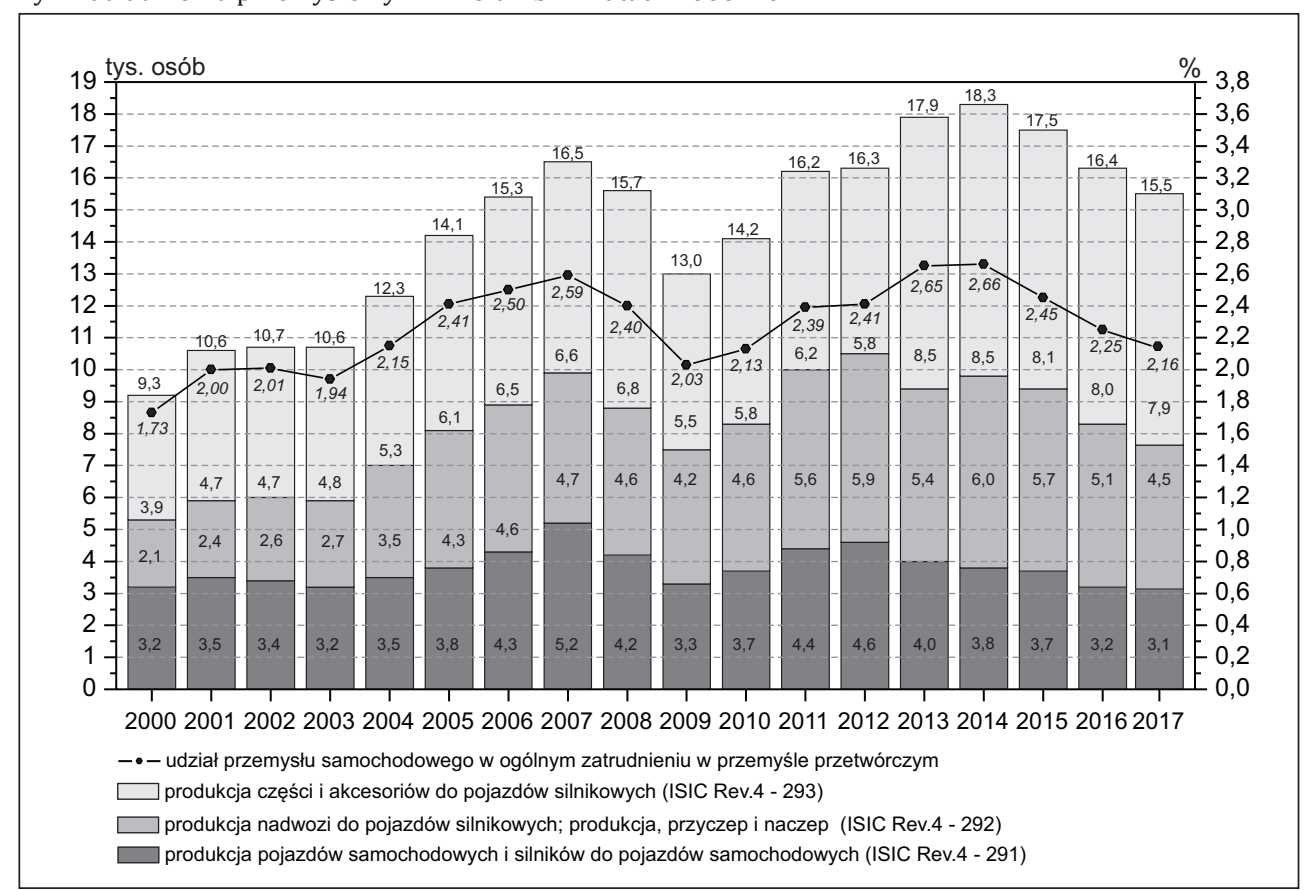

Źródło: opracowanie własne na podstawie danych Encuesta Anual Manufacturera 2000-2017 (2019) 
Rycina. 3. Zmiany wielkości produkcji samochodów oraz udziału eksportu w produkcji ogółem w Kolumbii w latach 2000-2017

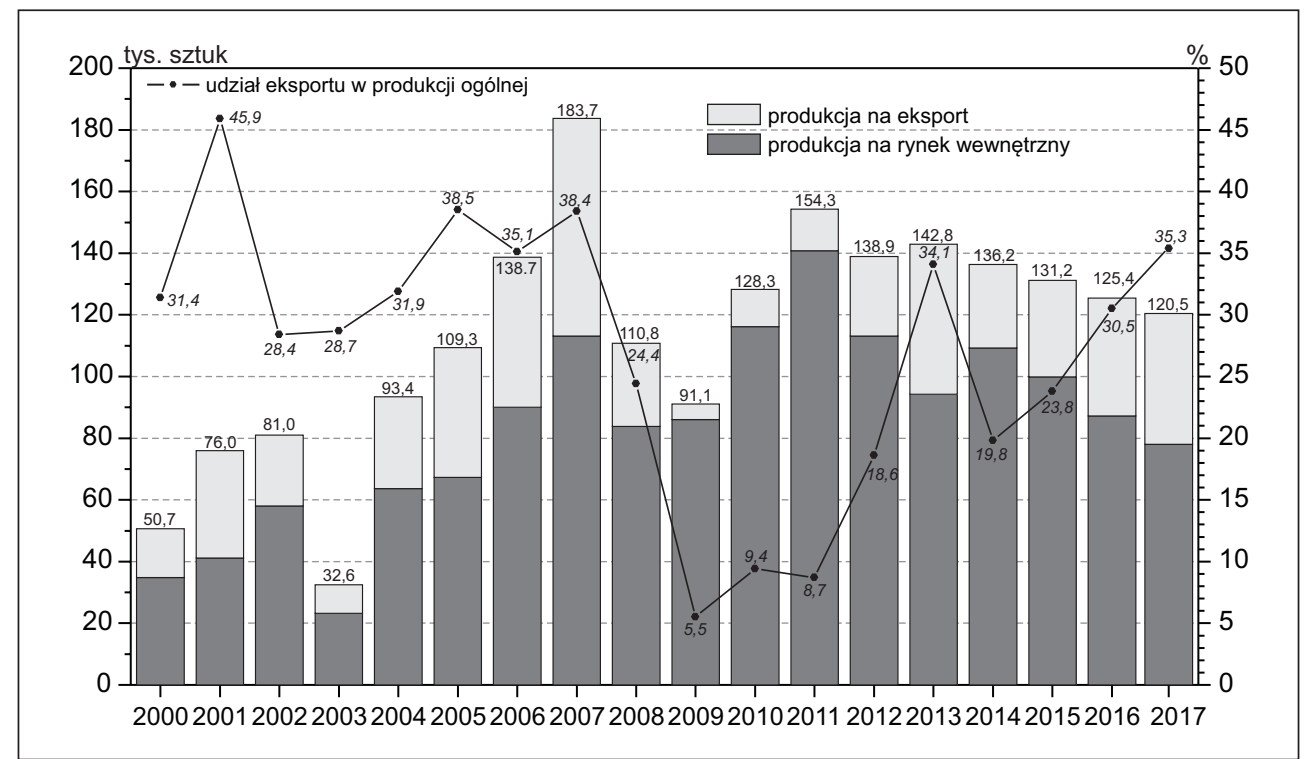

Źródło: opracowanie własne na podstawie ANDI (2017), Encuesta Anual Manufacturera (2019)

Produkcja samochodów w 2000 roku nieznacznie przekraczała 50 tys. sztuk, by po siedmiu latach osiągnąć poziom 183,7 tys. aut, z czego 38,4\% przeznaczono na eksport. Kryzys gospodarczy, który wybuchł rok później, bardzo mocno wpłynął na ograniczenie produkcji do poziomu 91,1 tys. sztuk w 2009 roku. Jednak w kolejnych latach zaczęła ona najpierw dynamicznie wzrastać, osiągając wielkość 154,3 tys. aut w 2011 roku, zaś następnie ponownie spadać do poziomu 125,4 tys. pojazdów w 2016 roku (rycina 3).

Warto również zwrócić uwagę, iż w latach 2014-2017, wraz ze spadkiem produkcji, coraz większa jej część przeznaczana była na eksport. Wynikało to z malejącego popytu na produkowane w kraju pojazdy przy jednoczesnym wzroście zainteresowania importowanymi. Wiąże się to w dużej mierze ze specyfiką miejscowych fabryk, nastawionych na produkcję tanich i prostych modeli dostępnych dla jak największej liczby klientów. Jednakże wraz z poprawą sytuacji gospodarczej w kraju i wzrostem zamożności ludności coraz bardziej rosną także jej wymagania związane z zakupem nowych aut, wpływając na wzrost importu luksusowych modeli. Należy również podkreślić, iż produkcja samochodów w stosunkowo niewielkim stopniu wykorzystuje zainstalowane moce produkcyjne, które jak wspomniano wcześniej, sięgają 320 tys. sztuk rocznie. Utrudnia to osiągnięcie odpowiednich korzyści skali oraz obniżenie kosztów produkcji. Nie zachęca także międzynarodowych koncernów do zwiększania ich zaangażowania w rozwój produkcji na miejscowym rynku (rycina 3).

Przykładem takiego zachowania może być wstrzymanie w kwietniu 2014 roku produkcji przez koncern Mazda, który po przejęciu w 1983 roku dawnych zakładów Fiata przez ponad 30 lat był ważnym producentem na kolumbijskim rynku. Wiązało się to z otwarciem dużej fabryki samochodów tego koncernu w Meksyku i możliwością ich taniego importu z tego kraju, co gwarantowały podpisane porozumienia (Rodríguez, 2014). 


\section{ZMIANY WIELKOŚCI POPYTU NA SAMOCHODY W KOLUMBII NA POCZĄTKU XXI WIEKU}

Wraz ze stabilizowaniem się sytuacji politycznej w Kolumbii oraz przyspieszeniem rozwoju gospodarczego w pierwszych dwóch dekadach XXI wieku odnotowano znaczący wzrost sprzedaży nowych pojazdów. W 2000 roku wielkość ta wynosiła zaledwie 60,4 tys. sztuk, by w 2011 osiągnąć poziom 332,7 tys. aut - najwyższy w historii kraju. W ostatnich kilku latach odnotowano znaczący spadek sprzedaży nowych aut, w 2017 roku wyniosła ona 238,2 tys. sztuk i była aż o $28,4 \%$ niższa w porównaniu z rekordowym rokiem. Jednakże w 2018 roku wzrosła do 256,6 tys. sztuk, co wskazuje na zahamowanie spadkowej tendencji (rycina 4).

Warto również zwrócić uwagę na zmiany w strukturze pochodzenia kupowanych pojazdów, wskazujące na stopniowy spadek udziału aut produkowanych w kraju, przy jednoczesnym dynamicznym zwiększeniu się udziału pojazdów importowanych. 0 ile jeszcze w 2002 roku pojazdy produkcji krajowej stanowiły 63,4\% ogólnej sprzedaży, to w szczytowym 2011 roku już zaledwie 40,6\%, a ostatnio udział ten spadł do 30,4\% w 2018 roku (rycina 4).

Wzrost znaczenia importowanych samochodów, wynikający z liberalnej polityki handlowej oraz podpisanych porozumień międzynarodowych, ograniczył możliwości rozwoju lokalnego przemysłu samochodowego. Boom na lokalnym rynku motoryzacyjnym jedynie nieznacznie przełożył się na wzrost sprzedaży samochodów produkowanych w Kolumbii, która w rekordowym 2011 roku sięgnęła niewiele ponad 135 tys. sztuk, jednakże do 2018 roku spadła do 77,9 tys. sztuk. Gwałtowny wzrost importu samochodów nie tylko zablokował możliwości pełnego wykorzystania mocy

Rycina 4. Zmiany liczby i pochodzenia sprzedawanych samochodów w Kolumbii w latach 2000-2018

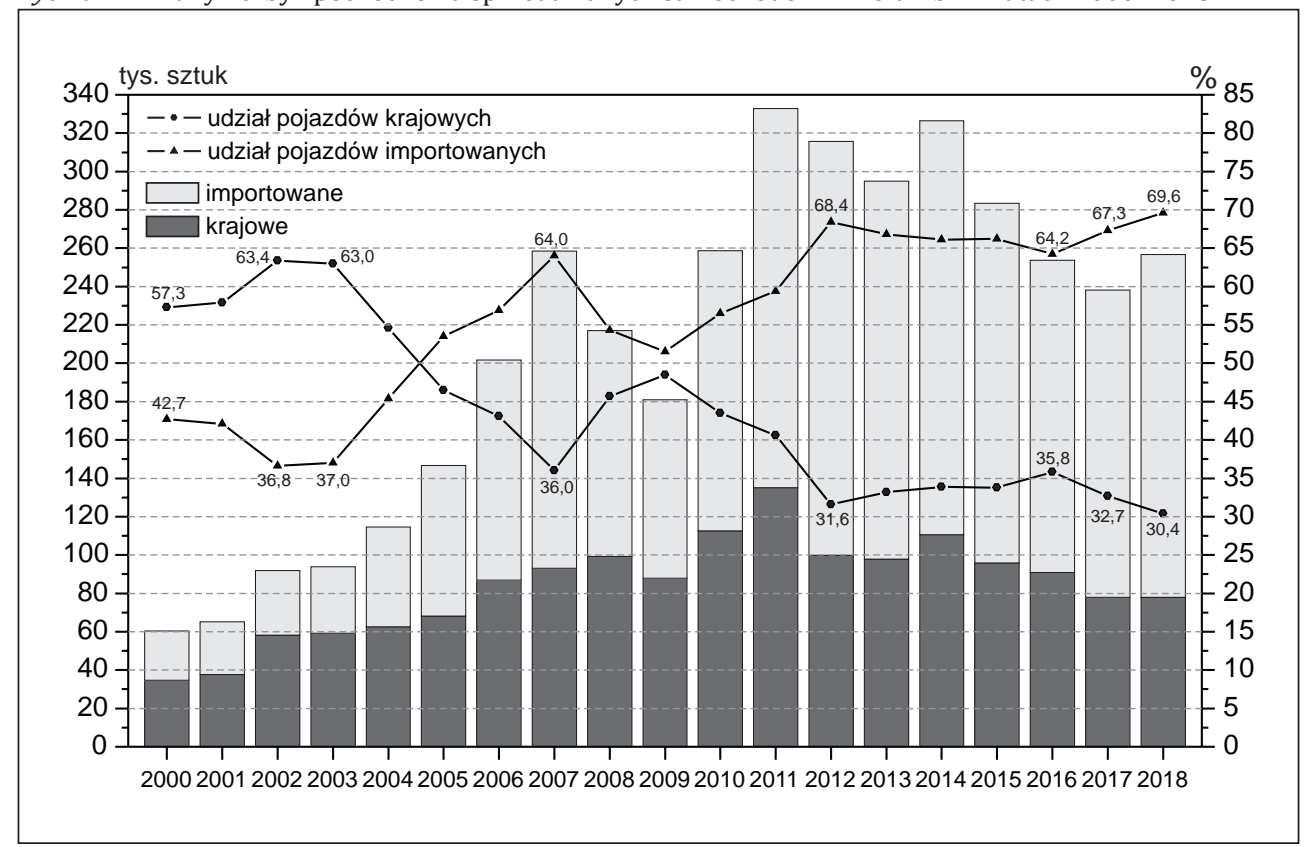

Źródło: opracowanie własne na podstawie danych ANDEMOS (2018) 
Rycina 5. Zmiany wielkości wymiany handlowej wyrobami przemysłu samochodowego oraz ich udział w ogólnej wartości handlu zagranicznego Kolumbii w latach 2000-2017

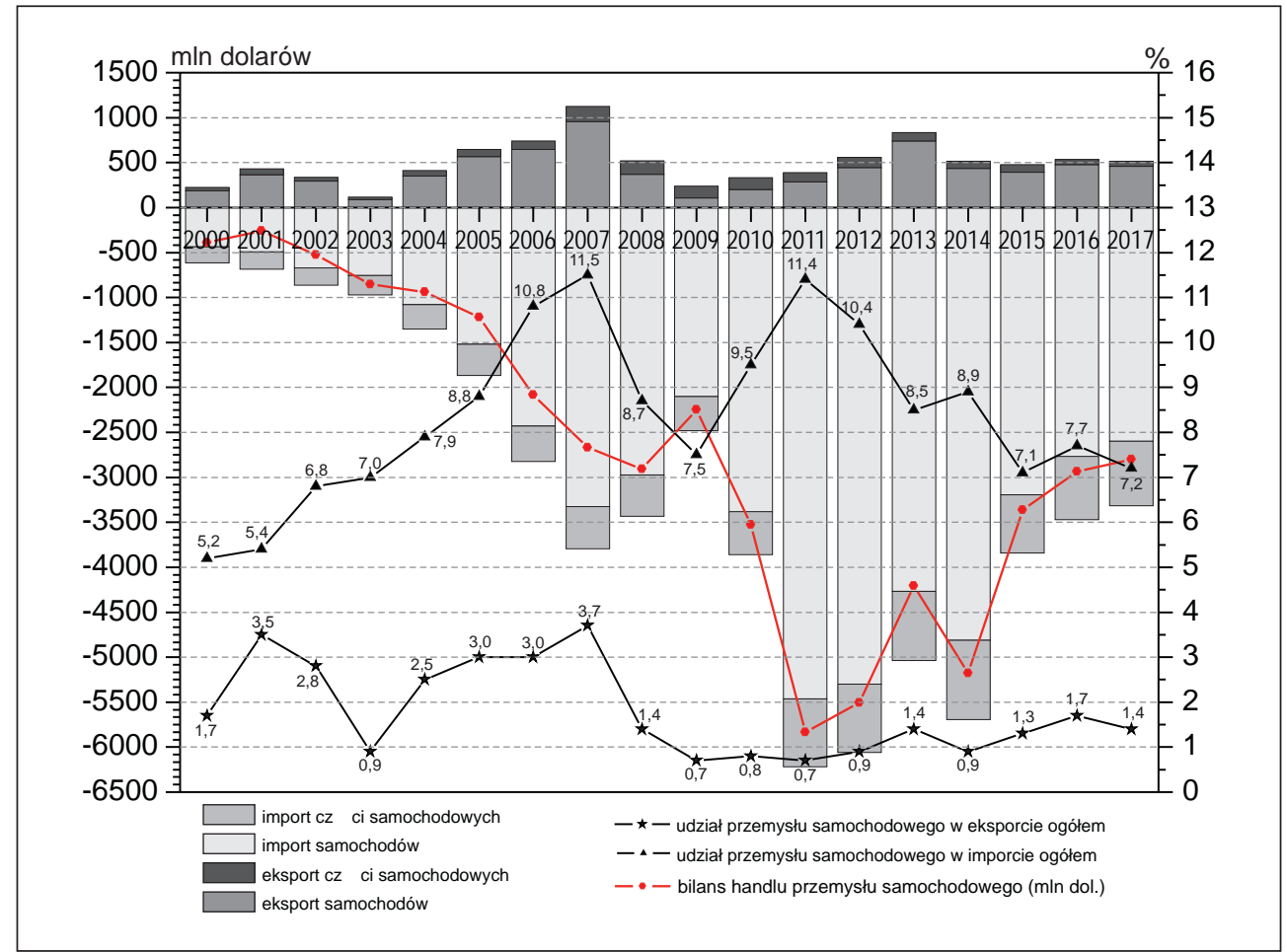

Źródło: opracowanie własne na podstawie UNCTAD (2017)

produkcyjnej lokalnych fabryk, ale także przyczynił się do wzrostu deficytu w handlu międzynarodowym.

W największym pod względem wielkości sprzedaży 2011 roku Kolumbijczycy kupili 197,7 tys. importowanych pojazdów, a łączna wartość importu wyrobów przemysłu samochodowego przekroczyła 6,22 mld dol., co stanowiło aż 11,4\% ogólnej wartości importu w tym roku. W kolejnych latach, wraz ze spadkiem sprzedaży zagranicznych aut do poziomu 160,3 tys. sztuk w 2017 roku, wartość importu tego sektora również zmalała do 3,32 mld dol. (ryciny 4 i 5).

Warto zwrócić uwagę, iż eksport wyrobów przemysłu samochodowego, choć w ostatnich dekadach znacznie wzrósł, nadal nie odgrywa większej roli w kolumbijskim eksporcie, stanowiąc w 2017 roku zaledwie 1,4\% jego całkowitej wartości. W szczytowym 2007 roku, kiedy to jego wartość przekroczyła 1,124 mld dol., udział tego sektora wynosił 3,7\% ogólnej wartości eksportu. W tym samym roku jednak udział importu wyrobów przemysłu samochodowego sięgał aż 11,5\% ogólnej wartości importu, co w liczbach bezwzględnych wynosiło blisko 3,795 mld dol. W wyniku takiej nierównowagi Kolumbia notowała ujemny bilans w handlu zagranicznym wyrobami przemysłu samochodowego, sięgający w 2007 roku 2,67 mld dol. Nie była to jednak najwyższa wartość, gdyż w szczytowym pod względem wielkości importu 2011 roku ujemny bilans wymiany handlowej w tym sektorze wyniósł ponad 5,8 mld dol. (rycina 5). 
Należy jednak podkreślić, iż w całym badanym okresie Kolumbia notuje ujemny bilans handlowy w przemyśle samochodowym, co jest wynikiem jego słabego zakorzenienia w lokalnej gospodarce i słabego rozwoju przemysłu produkującego części samochodowe. Wszystkie działające w kraju zakłady produkujące samochody zmuszone są do importu większości potrzebnych do ich produkcji części i podzespołów, co dodatkowo pogarsza bilans handlowy tego sektora (rycina 5).

W ostatnich latach w imporcie sektora motoryzacyjnego dominują głównie gotowe pojazdy, w 2017 roku stanowiące aż 78,4\% ogólnej jego wartości, a w rekordowym 2011 roku ich udział osiągnął aż 87,8\% (rycina 5). W latach 2014-2018 nadal najważniejszą pozycję zajmowały auta produkowane lokalnie, zaspokajające ok. 1/3 krajowego zapotrzebowania. Drugie miejsce zajmowały pojazdy importowane z Meksyku, które z kolei pokrywały ok. 1/5 krajowego popytu. Natomiast na trzecim miejscu znalazła się Korea Południowa, której udział w badanym okresie maleje. Niemniej jednak w 2018 roku koreańskie samochody nadal stanowiły 10,2\% ogólnej sprzedaży na kolumbijskim rynku (tabela 1).

Tabela 1. Główne kraje pochodzenia sprzedawanych w Kolumbii samochodów w latach 2014-2018

\begin{tabular}{|l|r|r|r|r|r|r|r|r|r|r|}
\hline \multirow{2}{*}{$\begin{array}{c}\text { Kraj } \\
\text { pochodzenia }\end{array}$} & \multicolumn{4}{|c|}{ Liczba pojazdów (w tys. sztuk) } & \multicolumn{5}{c|}{ Udział w sprzedaży (w \%) } \\
\cline { 2 - 13 } & 2014 & 2015 & 2016 & 2017 & 2018 & 2014 & 2015 & 2016 & 2017 & 2018 \\
\hline Kolumbia & 110,7 & 95,9 & 90,9 & 77,9 & 77,9 & 33,9 & 33,8 & 35,8 & 32,7 & 30,4 \\
\hline Meksyk & 57,3 & 57,1 & 48,6 & 46,8 & 48,4 & 17,5 & 20,1 & 19,2 & 19,6 & 18,8 \\
\hline $\begin{array}{l}\text { Korea } \\
\text { Południowa }\end{array}$ & 54,5 & 47,2 & 34,8 & 30,1 & 26,2 & 16,7 & 16,6 & 13,7 & 12,6 & 10,2 \\
\hline Brazylia & 9,2 & 8,8 & 13,3 & 16,9 & 25,3 & 2,8 & 3,1 & 5,2 & 7,1 & 9,8 \\
\hline UE 28 & 13,2 & 14,3 & 14,3 & 13,3 & 17,8 & 4,0 & 5,0 & 5,6 & 5,6 & 6,9 \\
\hline Japonia & 18,7 & 14,9 & 14,5 & 16,7 & 17,7 & 5,7 & 5,3 & 5,7 & 7,0 & 6,9 \\
\hline Tajlandia & 9,4 & 6,4 & 6,2 & 9,2 & 11,8 & 2,9 & 2,3 & 2,4 & 3,9 & 4,6 \\
\hline Chiny & 23,3 & 17,4 & 12,9 & 10,8 & 10,3 & 7,1 & 6,1 & 5,1 & 4,5 & 4,0 \\
\hline USA & 11,6 & 7,7 & 8,0 & 8,1 & 8,8 & 3,6 & 2,7 & 3,1 & 3,4 & 3,4 \\
\hline Indie & 10,4 & 7,3 & 2,8 & 4,2 & 4,1 & 3,2 & 2,6 & 1,1 & 1,7 & 1,6 \\
\hline Pozostałe & 8,2 & 6,5 & 7,4 & 4,3 & 8,4 & 2,5 & 2,3 & 2,9 & 1,8 & 3,3 \\
\hline Ogółem & 326,3 & 283,4 & 253,7 & 238,2 & 256,7 & 100,0 & 100,0 & 100,0 & 100,0 & 100,0 \\
\hline
\end{tabular}

Źródło: opracowanie własne na podstawie ANDEMOS (2018)

Warto również zwrócić uwagę na wzrost znaczenia pojazdów importowanych z Brazylii. W analizowanym okresie ich liczba wzrosła blisko trzykrotnie - do 25,3 tys., co stanowiło 9,8\% ogólnej wielkości sprzedaży w 2018 roku i plasowało ten kraj na czwartej pozycji. Podobną tendencję wzrostową w liczbie sprowadzanych pojazdów obserwujemy również w przypadku Japonii oraz państw UE 28, choć wielkość tego wzrostu jest niższa niż dla Brazylii. Biorąc jednak pod uwagę, iż w analizowanym okresie następował stopniowy spadek wielkości sprzedaży samochodów, obserwowana w przypadku tych państw odwrotna tendencja świadczyć może o szczególnej popularności importowanych z nich aut. Może ona także wynikać z faktu, iż ich odbiorcami są przedstawiciele zamożniejszej części społeczeństwa, której potrzeby konsumpcyjne w tym zakresie nie zostały jeszcze ograniczone. Odmienną sytuację obserwujemy dla pojazdów importowanych z Chin, Indii czy Tajlandii. Są to w zdecydowanej większości tańsze modele, przeznaczone dla mniej zamożnych klientów, których decyzje 
zakupowe są silnie uzależnione od sytuacji gospodarczej kraju i możliwości i kosztów kredytowania zakupu pojazdu. W ostatnich latach zaszły w tym względzie niekorzystne zmiany, co przełożyło się na spadek liczby sprzedawanych aut, co jest szczególnie widoczne w przypadku importu z Chin i Indii (tabela 1).

Dominującą rolę na kolumbijskim rynku motoryzacyjnym odgrywają dwa koncerny samochodowe - GM i Renault, których łączny udział w sprzedaży co roku przekraczał $40 \%$. Oba posiadają w Kolumbii zakłady produkcyjne mające długie tradycje i specjalizujące się w produkcji tanich modeli, cieszących się największą popularnością wśród klientów. Na trzecim miejscu znalazł się koreański koncern Hyundai Motor Group, którego obie marki (Hyundai i Kia) cieszą się dużym wzięciem. W 2013 roku ich łączny udział stanowił 17,3\% sprzedaży nowych pojazdów, a w 2018 roku zmniejszył się do 10,1\%, głównie za sprawą spadku sprzedaży samochodów marki Hyundai. Modele tej marki przeznaczone są dla bardziej zamożnych odbiorców, a rywalizacja o klienta w tym segmencie rynku jest bardzo silna. Zatem w sytuacji pogorszenia się koniunktury gospodarczej oraz nastrojów konsumenckich sprzedaż tych aut gwałtownie spadła. Zdecydowanie lepiej radziła sobie druga marka tego koncernu - Kia, która jest tańsza i przeznaczona dla mniej zamożnych odbiorców. W jej przypadku również odnotowano spadek sprzedaży, niemniej jednak był on znacznie mniejszy i pozwolił w zasadzie utrzymać udziały w miejscowym rynku (tabela 2).

Tabela 2. Udział głównych marek w wielkości sprzedaży samochodów w Kolumbii w latach 2013-2018

\begin{tabular}{|l|r|r|r|r|r|r|r|r|r|r|r|r|}
\hline \multirow{2}{*}{$\begin{array}{c}\text { Główne } \\
\text { marki }\end{array}$} & \multicolumn{5}{|c|}{ Liczba pojazdów (w tys. sztuk) } & \multicolumn{4}{c|}{ Udział w sprzedaży (w \%) } \\
\cline { 2 - 14 } & 2013 & 2014 & 2015 & 2016 & 2017 & 2018 & 2013 & 2014 & 2015 & 2016 & 2017 & 2018 \\
\hline Chevrolet & 75,9 & 82,1 & 67,8 & 60,1 & 51,3 & 49,9 & 25,7 & 25,2 & 23,9 & 23,7 & 21,5 & 19,4 \\
\hline Renault & 43,0 & 49,9 & 49,0 & 50,9 & 46,9 & 49,7 & 14,6 & 15,3 & 17,3 & 20,1 & 19,7 & 19,4 \\
\hline Nissan & 20,3 & 21,3 & 20,2 & 18,3 & 21,1 & 23,2 & 6,9 & 6,5 & 7,1 & 7,2 & 8,8 & 9,0 \\
\hline Mazda & 9,3 & 11,4 & 15,8 & 18,1 & 18,7 & 21,5 & 3,2 & 3,5 & 5,6 & 7,2 & 7,8 & 8,4 \\
\hline Kia & 28,4 & 31,7 & 28,4 & 26,3 & 19,8 & 21,0 & 9,6 & 9,7 & 10,0 & 10,4 & 8,3 & 8,2 \\
\hline Toyota & 14,3 & 13,8 & 9,0 & 8,5 & 9,6 & 14,2 & 4,8 & 4,2 & 3,2 & 3,4 & 4,0 & 5,5 \\
\hline Volkswagen & 9,4 & 10,2 & 8,2 & 8,6 & 9,3 & 13,4 & 3,2 & 3,1 & 2,9 & 3,4 & 3,9 & 5,2 \\
\hline Ford & 17,1 & 21,3 & 16,2 & 16,0 & 15,2 & 12,5 & 5,8 & 6,5 & 5,7 & 6,3 & 6,4 & 4,9 \\
\hline Hyundai & 22,6 & 21,3 & 17,6 & 6,0 & 8,6 & 4,9 & 7,7 & 6,5 & 6,2 & 2,4 & 3,6 & 1,9 \\
\hline Pozostałe & 54,6 & 63,4 & 51,2 & 40,9 & 37,9 & 46,4 & 18,5 & 19,4 & 18,1 & 16,1 & 15,9 & 18,1 \\
\hline Ogółem & 294,9 & 326,3 & 283,4 & 253,7 & 238,2 & 256,7 & 100,0 & 100,0 & 100,0 & 100,0 & 100,0 & 100,0 \\
\hline
\end{tabular}

Źródło: opracowanie własne na podstawie danych ANDEMOS (2018)

Ważne miejsce na kolumbijskim rynku zajmuje również Mazda, która jak już wspomniano wcześniej, w 1983 roku przejęła od Fiata zakłady CCA i do kwietnia 2014 roku produkowała w nich auta na lokalny rynek. Pomimo zawieszenia produkcji i importu samochodów z nowo otwartej fabryki w Meksyku w latach 2012-2018 udało się jej zwiększyć sprzedaż o 11 tys. sztuk, a wraz z nią udział w rynku z 3,5\% do 8,4\% (tabela 2).

Mocną pozycję na kolumbijskim rynku samochodowym mają również koncerny Nissan i Ford. Pierwszy z nich, pomimo dużych wahań wielkości sprzedaży, umocnił swój udział w rynku. Natomiast Fora w ostatnich latach traci swoją pozycję. Odwrotną tendencję zaobserwowano w przypadku koncernu Volkswagen, który ostatnio znacząco zwiększył liczbę sprzedawanych w Kolumbii aut (tabela 2). 


\section{PRZESTRZENNE ZRÓŻNICOWANIE WIELKOŚCI POPYTU NA SAMOCHODOWY W KolumbiI}

Bardzo ważną cechą kolumbijskiego rynku motoryzacyjnego jest silna koncentracja sprzedaży w stolicy oraz szerzej w regionie andyjskim. Co prawda, w latach 2013-2018 udział rejestracji nowych pojazdów w tym regionie obniżył się z 52,2\% do 48\% ogólnej ich liczby w Kolumbii, to jednak nadal silnie dominuje on nad pozostałymi. Warto również podkreślić, iż w tym samym okresie udział rejestracji nowych pojazdów w samej Bogocie zmniejszył się z 38,5\% do 32,6\% ich ogólnej liczby w kraju. Po zsumowaniu liczby rejestracji nowych aut w Bogocie oraz departamencie Cundinamarca, na obszarze którego leży stolica, ich łączny udział waha się od 45,4\% w 2012 roku do 40,9\% w 2017 roku (tabela 3).

Pozytywną tendencją zaobserwowaną w badanym okresie jest stopniowy spadek udziału regionu andyjskiego i Bogoty w liczbie nowych rejestracji pojazdów, co może wskazywać na wzrost znaczenia pozostałych regionów, wynikający z ich szybszego rozwoju gospodarczego, wyrównującego nierówności regionalne i zwiększającego siłę nabywczą ich mieszkańców. Na szczególną uwagę zasługuje region Pacyfiku, który zwiększył udział w liczbie nowych rejestracji pojazdów z 11,6\% do 14\% (tabela 3). Dominującą rolę w tym regionie odgrywa departament Valle de Cauca, którego stolicą jest największe miasto w regionie - Cali, liczące ponad 2,4 mln mieszkańców. Departament ten charakteryzuje się również wysokim wskaźnikiem gęstości sieci drogowej (rycina 6).

Tabela. 3. Nowe rejestracje pojazdów według regionów Kolumbii w latach 2013-2018

\begin{tabular}{|l|r|r|r|r|r|r|}
\hline \multirow{2}{*}{ Regiony } & \multicolumn{7}{c|}{ Liczba pojazdów (w tys. sztuk) } \\
\cline { 2 - 7 } & 2013 & 2014 & 2015 & 2016 & 2017 & 2018 \\
\hline Andyjski & 153,6 & 166,6 & 136,6 & 120,9 & 112,2 & 123,1 \\
\hline w tym: Bogota D.C. & 113,3 & 120,0 & 94,7 & 85,2 & 80,3 & 83,7 \\
\hline Antioquia-Santander & 61,6 & 67,5 & 60,1 & 54,7 & 52,7 & 58,3 \\
\hline Atlantycki & 30,3 & 32,6 & 30,0 & 25,0 & 23,0 & 23,0 \\
\hline Pacyficzny & 34,2 & 41,3 & 39,8 & 37,5 & 35,3 & 35,8 \\
\hline Kawowy & 12,4 & 15,1 & 14,5 & 13,6 & 13,3 & 14,1 \\
\hline Wschodni & 2,3 & 2,9 & 2,4 & 1,9 & 1,7 & 2,3 \\
\hline Ogółem & 294,4 & 326,0 & 283,4 & 253,7 & 238,2 & 256,7 \\
\hline & & & Udział w rejestracji (w \%) & & 2018 \\
\hline \multicolumn{1}{|c|}{ Regiony } & 2013 & 2014 & 2015 & 2016 & 2017 & 48,0 \\
\hline Andyjski & 52,2 & 51,1 & 48,2 & 47,7 & 47,1 & 32,6 \\
\hline w tym: Bogota D.C. & 38,5 & 36,8 & 33,4 & 33,6 & 33,7 & 22,7 \\
\hline Antioquia-Santander & 20,9 & 20,7 & 21,2 & 21,6 & 22,1 & 9,0 \\
\hline Atlantycki & 10,3 & 10,0 & 10,6 & 9,8 & 9,6 & 14,0 \\
\hline Pacyficzny & 11,6 & 12,7 & 14,0 & 14,8 & 14,8 & 5,5 \\
\hline Kawowy & 4,2 & 4,6 & 5,1 & 5,4 & 5,6 & 0,9 \\
\hline Wschodni & 0,8 & 0,9 & 0,9 & 0,8 & 0,7 & 100,0 \\
\hline Ogółem & 100,0 & 100,0 & 100,0 & 100,0 & 100,0 & \\
\hline
\end{tabular}

Źródło: opracowanie własne na podstawie danych Informe del sector... (2015), ANDEMOS (2018)

Przestrzenne zróżnicowanie liczby nowych rejestracji pojazdów jest bardzo mocno związane z poziomem rozwoju gospodarczego poszczególnych departamentów, 
Rycina 6. Nowe rejestracje pojazdów w roku 2015 i 2017 oraz gęstość sieci głównych dróg w roku 2017 według departamentów Kolumbii

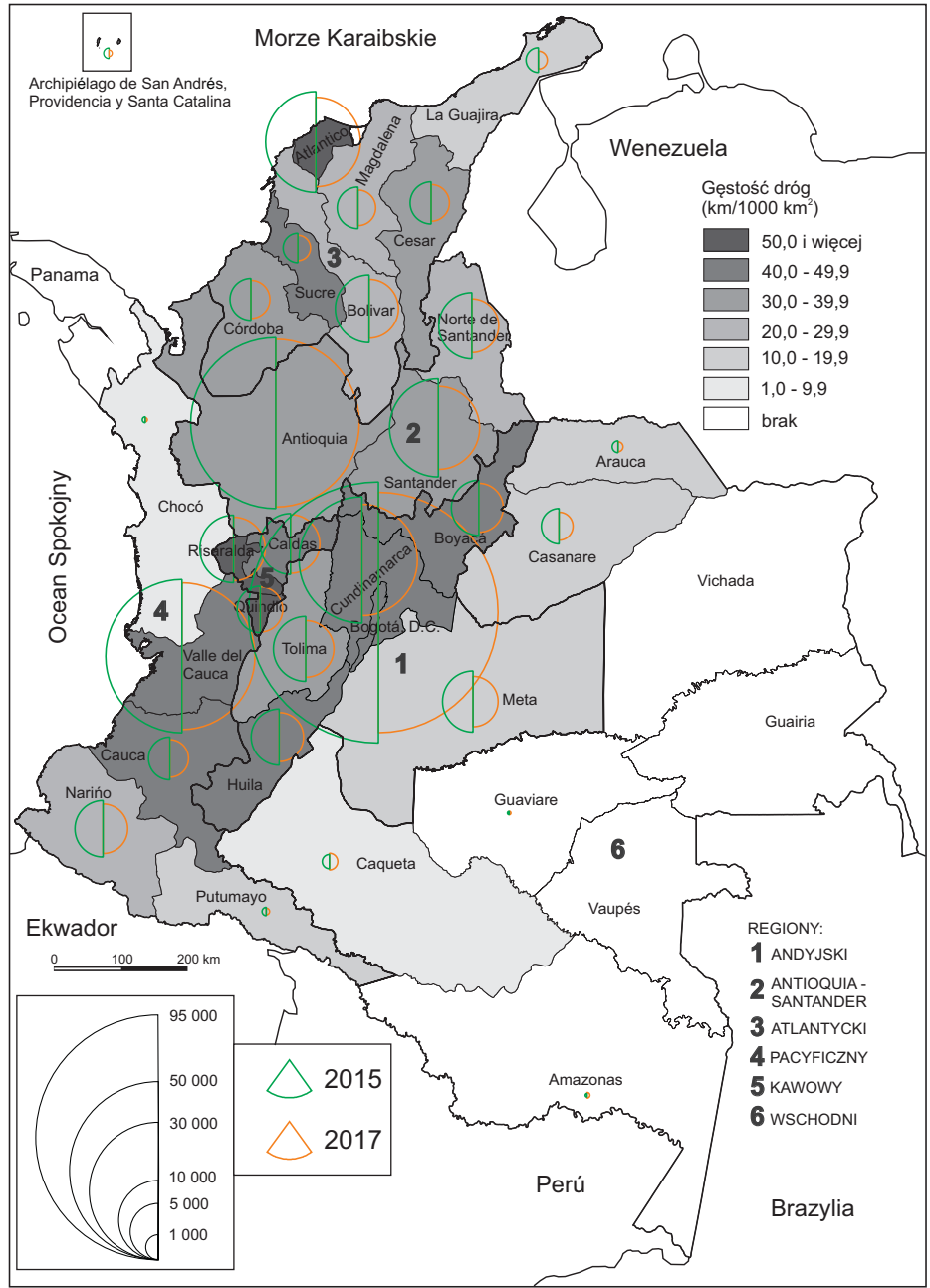

Źródło: opracowanie własne na podstawie ANDEMOS (2018), Transporte... (2018)

a także uwarunkowane poziomem urbanizacji i rozwoju infrastruktury drogowej. W departamentach dobrze rozwiniętych gospodarczo i infrastrukturalnie, mających na swoim obszarze duże aglomeracje miejskie, odnotowano zdecydowanie większą liczbę nowych rejestracji. Przykładem, poza wspomnianym powyżej departamentem Valle de Cauca, może być departament Antioquia, którego stolicą jest Medellín, drugie pod względem liczby ludności miasto w Kolumbii. Departament ten zajmuje drugie miejsce po stolicy pod względem nowych rejestracji pojazdów, których liczba w 2017 roku przekroczyła 39,1 tys. Na uwagę zasługują także departamenty Santander i Atlantico, którego stolicą jest Barranquilla - czwarte co do wielkości miasto Kolumbii i zarazem największy port nad Morzem Karaibskim. Wymienione departamenty cechują się także relatywnie wysokimi wartościami wskaźnika gęstości sieci drogowej (rycina 6). 
Najmniejsze wartości rejestracji nowych pojazdów odnotowano natomiast w regionie wschodnim (Oriente). Obejmuje on najsłabiej zaludnione i wyposażone w infrastrukturę departamenty leżące w obrębie nizinnych terenów w dorzeczu Amazonki i Orinoko, co nie sprzyja rozwojowi motoryzacji. Jedynie w przypadku departamentów: Casanare, Caqueta i Arauca odnotowano niewielką liczbę nowych rejestracji, jednakże udział tego regionu w ogólnej ich liczbie w kraju kształtuje się poniżej 1\% (tabela 4, rycina 6).

Dzięki gwałtownemu wzrostowi sprzedaży i rejestracji nowych pojazdów na początku XXI wieku park samochodowy Kolumbii zwiększył się ponad dwukrotnie z 2,55 mln w 2001 roku do ponad 5,87 mln aut w roku 2016. Znacznie szybsze tempo wzrostu odnotowano w przypadku samochodów osobowych, których liczba zwiększyła się o 142,2\% i stanowiły one w 2017 roku aż 60\% ogółu zarejestrowanych pojazdów (tabela 5).

Warto również podkreślić, iż w Kolumbii bardzo ważną rolę odgrywają także motocykle. W 2017 roku zarejestrowanych było ich blisko 7,5 mln, a wskaźnik ich liczby na 100 mieszkańców wynosił ponad 15 (Transporte..., 2018). Tak wysoka wartość była porównywalna z poziomem nasycenia rynku typowym dla najlepiej pod tym względem rozwiniętych krajów południa Europy (Dorocki, 2018). W kolejnym roku odnotowano niestety spadek liczby zarejestrowanych pojazdów i to pomimo wzrostu sprzedaży nowych aut. Tak nietypową sytuację można wyjaśnić, biorąc pod uwagę proces wyrejestrowywania starych aut. W 2016 roku średni wiek samochodów wynosił 15,7 lat, natomiast pojazdy do pięciu lat stanowiły tylko 27,7\% ogółu zarejestrowanych, podczas gdy starsze niż 20 lat aż 33,8 (Presentación..., 2017)

Wzrost liczby zarejestrowanych samochodów zaowocował także zmianą wartości wskaźnika motoryzacji z poziomu 63 do 120 pojazdów na 1000 mieszkańców w latach 2001-2016, jednakże w 2017 roku jego wartość obniżyła się do 110 (tabela 4). Wskazuje to na znaczącą poprawę poziomu motoryzacji. Niemniej jednak, biorąc pod uwagę fakt, iż w większości państw wysoko rozwiniętych wskaźnik ten przekracza 500 pojazdów na 1000 mieszkańców, kolumbijski rynek jest jeszcze daleki od osiągniecia pełnego nasycenia. Jeżeli sytuacja gospodarcza będzie nadal stabilna, należy spodziewać się utrzymania wysokiego poziomu sprzedaży nowych samochodów, która będzie silnie powiązana z poprawą dochodów ludności. Wzrost sprzedaży samochodów będzie także wzmacniany koniecznością zastępowania starych pojazdów, gdyż jak już wspomniano, aż 1/3 parku samochodowego ma powyżej 20 lat (Presentación..., 2017).

Tabela 4. Zmiany wielkości parku samochodowego w Kolumbii w latach 2001-2017

\begin{tabular}{|l|c|c|c|c|c|c|c|}
\hline \multirow{2}{*}{ Rok } & \multicolumn{2}{|c|}{ Samochody osobowe } & \multicolumn{2}{c|}{ Pozostałe samochody } & \multicolumn{2}{c|}{ Ogółem } & \multirow{2}{*}{$\begin{array}{c}\text { Wskaźnik } \\
\text { motoryzacji }\end{array}$} \\
\cline { 2 - 7 } & tys. sztuk & $\begin{array}{c}\text { zmiana } \\
\text { w \% }\end{array}$ & tys. sztuk & $\begin{array}{c}\text { zmiana } \\
\text { w } \%\end{array}$ & tys. sztuk & $\begin{array}{c}\text { zmiana } \\
\text { w } \%\end{array}$ & \\
\hline 2001 & 1393,8 & 100,0 & 1158,0 & 100,0 & 2551,8 & 100,0 & 63 \\
\hline 2005 & 1675,9 & 120,2 & 1285,4 & 111,0 & 2961,3 & 116,0 & 69 \\
\hline 2010 & 2328,8 & 167,1 & 1698,1 & 146,6 & 4026,9 & 157,8 & 88 \\
\hline 2016 & 3376,1 & 242,2 & 2497,7 & 215,7 & 5873,8 & 230,2 & 120 \\
\hline 2017 & 3243,9 & 232,7 & 2160,4 & 186,6 & 5404,3 & 211,8 & 110 \\
\hline
\end{tabular}

Źródło: opracowanie własne na podstawie danych Transporte... (2018)

Warto również podkreślić, że park motoryzacyjny Kolumbii wykazuje bardzo silną koncentrację przestrzenną, zresztą podobnie jak analizowane powyżej regionalne 
zróżnicowanie liczby rejestracji nowych pojazdów. Aż 50\% samochodów zarejestrowanych jest w stolicy oraz departamencie Cundinamarca. Na kolejnych miejscach znajdują się departamenty: Antioquia (16\%), Valle del Cauca (12\%), Santander (6\%) i Atlantico (5\%). W tych pięciu spośród 32 departamentów zarejestrowanych było 89\% pojazdów dopuszczonych do ruchu w 2016 roku (Presentación..., 2017).

Nowe rejestracje wykazują natomiast wyraźną współzależność z poziomem rozwoju gospodarczego oraz infrastrukturalnego poszczególnych departamentów. W pierwszym przypadku wyróżnia się szczególnie dystrykt stołeczny Bogoty notujący najwyższe wartości wskaźnika sprzedaży nowych aut przy jednocześnie wysokim poziomie PKB per capita w porównaniu do średniej krajowej. Ciekawą sytuację odnotowano w przypadku departamentów: Casanare, Meta i Santander, które charakteryzowały się wysokim poziomem rozwoju gospodarczego na tle kraju, ale relatywnie niskim wskaźnikiem sprzedaży nowych aut. W przypadku dwóch pierwszych departamentów może się to wiązać ze stosunkowo kiepskim poziomem rozwoju sieci drogowej. Jednocześnie wysokie wartości PKB per capita wynikają głównie z wydobycia ropy naftowej i gazu ziemnego, co nie przekłada się na realne dochody ludności (rycina 7).

Rycina 7. Współzależności między wskaźnikiem sprzedaży nowych aut a poziomem rozwoju gospodarczego (A) oraz gęstością sieci głównych dróg (B) według departamentów Kolumbii w 2016 roku

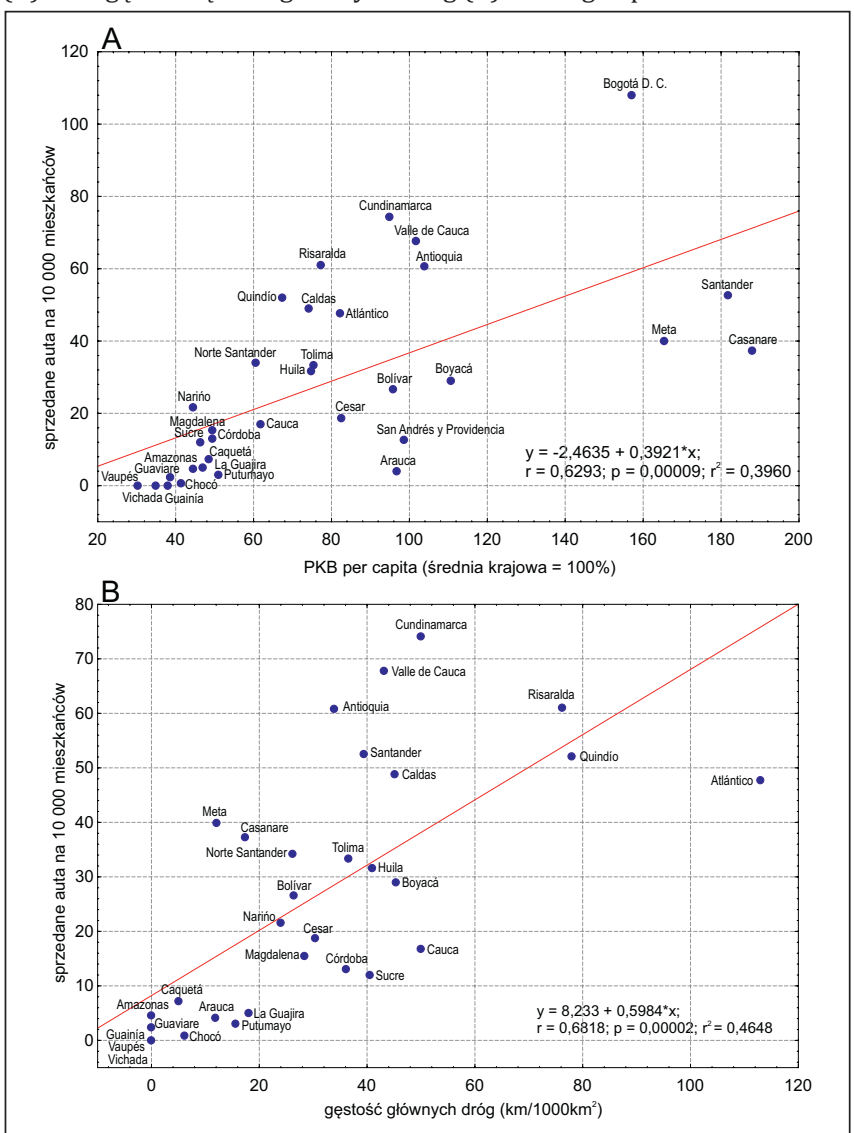

Źródło: opracowanie własne na podstawie danych ANDEMOS (2018), Transporte... (2017), DANE (2018) 
Na przeciwległym biegunie znajdują się natomiast departamenty Cundinamarca, Valle de Cauca i Antioquia, które notują zbliżony do średniej krajowej poziom PKB per capita, ale charakteryzują się relatywnie wysokimi wartościami wskaźnika sprzedaży nowych aut. Mają one relatywnie dobry stan infrastruktury drogowej oraz wysoki poziom urbanizacji. Jak już wspomniano, w pierwszym z nich leży stolica kraju, traktowana często jako odrębna jednostka ze względu na swój duży potencjał demograficzny i gospodarczy, w drugim znajduje się miasto Cali, a w trzecim - Medelin (rycina 7).

W przypadku departamentów o PKB per capita dużo niższym od średniej krajowej spadają także wskaźniki sprzedaży nowych aut. Niskie wartości sprzedaży nowych aut odnotowano także w departamentach o słabo rozwiniętej sieci głównych dróg (rycina 7).

\section{PoDsumOWANIE}

Obserwowany w ostatnich dekadach gwałtowny wzrost sprzedaży samochodów przyczynił się do ponad dwukrotnego zwiększenia się parku samochodowego w Kolumbii. W tym samym okresie wartość wskaźnika motoryzacji również wzrosła blisko dwukrotnie, co wskazuje na znaczący rozwój motoryzacji. W latach 2006-2017 notowano najwyższe w historii kraju liczby sprzedawanych pojazdów, w rekordowym 2011 roku było to 332,7 tys. aut. Jednakże lokalny przemysł samochodowy tylko nieznacznie wykorzystał boom motoryzacyjny do dalszego rozwoju. Wprawdzie wielkość sprzedaży krajowej produkcji samochodów znacząco wzrosła w analizowanym okresie w porównaniu do początku XXI wieku, jednak prowadzona przez rząd liberalna polityka handlowa sprawiła, iż większa część popytu została zaspokojona przez import. Przyczyniło się to do gwałtownego wzrostu deficytu w obrotach handlowych wyrobami przemysłu samochodowego, zaś import pojazdów stał się jedną z najważniejszych pozycji w ogólnej strukturze importu.

Słabość kolumbijskiego przemysłu samochodowego wynika z jego niewielkiego zakorzenienia w miejscowej gospodarce, a szczególnie niedorozwoju sektora produkcji części samochodowych. Konsekwencją tego jest silne uzależnienie lokalnej produkcji od ich importu, co sprawia, że ma ona raczej charakter montażu z importowanych podzespołów niż produkcji w większości opartej na lokalnych dostawcach. Wysoki udział importowanych części nie sprzyja również obniżeniu kosztów produkcji, co przy stosunkowo niewielkiej jej skali dodatkowo obniża jej konkurencyjność wobec importu gotowych pojazdów.

Ponadto słabo rozwinięty sektor produkcji części samochodowych nie wytworzył silnego lobby wśród rządzących elit, co pozwoliłoby na przeforsowanie polityki bardziej chroniącej lokalny przemysł samochodowy i wymuszało wzrost kooperacji z lokalnymi dostawcami. Wobec słabości tego sektora oraz jego niewielkiego znaczenia, zarówno w strukturze zatrudnienia, jak i tworzenia wartości dodanej, kolejne rządy starały się raczej prowadzić liberalną politykę handlową. Bardziej protekcyjna polityka doprowadziłaby bowiem do wzrostu cen nie tylko importowanych pojazdów, ale także wśród miejscowych producentów, co ograniczyłoby ich dostępność dla mniej zamożnej części rozrastającej się klasy średniej.

Zaobserwowano korelację między poziomem rozwoju gospodarczego mierzonego wskaźnikiem PKB per capita a wielkością sprzedaży nowych aut. Warto jednak zwrócić uwagę, że w przypadku kilku departamentów położonych w centralnej części kraju i notujących wysoki poziom PKB per capita odnotowano relatywnie niskie wartości 
wskaźnika sprzedaży nowych aut. Wynikało to głownie z faktu, iż departamenty te dzięki zyskom z wydobycia ropy naftowej i innych surowców mineralnych osiągały wysokie wartości wskaźnika PKB per capita, choć nie przekładało się to bezpośrednio na zamożność ich mieszkańców. Zaobserwowano również istotną współzależność wskazującą na większe zapotrzebowanie na nowe auta w departamentach cechujących się wyższym poziomem rozwoju sieci drogowej. Wskaźnik gęstości sieci dróg pośrednio również informuje o poziomie rozwoju gospodarczego poszczególnych departamentów, gdyż osiąga on najwyższe wartości w tych z nich, które notują również wysokie wartości PKB per capita, dużą gęstość zaludnienia oraz wysoki poziom urbanizacji.

W polityce kolejnych rządów da się zauważyć dążenie do zwiększenia wielkości rynku wewnętrznego na nowe samochody. W Kolumbii, dysponującej stosunkowo skromnie rozwiniętym sektorem motoryzacyjnym, powstałym w okresie industrializacji poprzez substytucję importu, rządzący starają się przede wszystkim zwiększyć wielkość sprzedaży nowych pojazdów, licząc, że dzięki odpowiednio chłonnemu rynkowi motoryzacyjnemu uda się przyciągnąć kolejne inwestycje, zwiększające potencjał produkcyjny. Od wielkości rynku, będącego swoistą marchewką dla inwestorów, będzie również zależało, jak wielkiego kija, w postaci przepisów chroniących przed swobodnym importem, będzie można użyć, aby skłonić ich do inwestycji w rozwój lokalnej produkcji.

Biorąc pod uwagę fakt, iż w ostatnich latach Kolumbia stała się piątym pod względem wielkości rynkiem motoryzacyjnym w Ameryce Łacińskiej (po Brazylii, Meksyku, Argentynie i Chile), na którym w rekordowym 2011 roku sprzedaż przekroczyła nominalną moc produkcyjną działających w tym kraju fabryk, można przypuszczać, że miejscowy przemysł samochodowy może zyskać impuls do dalszego rozwoju. Będzie on jednak zależał od dalszego wzrostu wielkości sprzedaży oraz od odpowiedniej polityki władz, zachęcającej do nowych inwestycji. Symptomem rozwoju tego sektora może być podwojenie wielkości zatrudnienia w produkcji części samochodowych w latach 2000-2016. Warto również pamiętać, że rozwój współpracy i znoszenie barier w wymianie handlowej w ramach Wspólnoty Andyjskiej oraz w kontaktach z innymi państwami regionu może znacząco poszerzyć rynek zbytu dla kolumbijskiego przemysłu samochodowego.

\section{Literatura \\ References}

ANDEMOS (2018). Informe Vehículos. Asociación Colombiana de Vehículos Automotores ANDEMOS. Bogota. Pozyskano z http://www.andemos.org/index.php/cifras-y-estadisticas-version-2/

ANDI (2017). Información general. La Cámara de la Industria Automotriz de la ANDI. Pozyskano z http://www.andi.com.co/Home/Camara/4

Bértola, L., Ocampo, J.A. (2012). The Economic Development of Latin America since Independence. Oxford: Oxford University Press.

Cárdenas, M.P. (1998). Restructuring in the Colombian Auto Industry: A Case Study of Conflict at Renault. W: J.P. Tuman, J.T. Morris (red.). Transforming the Latin American Automobile Industry: Unions, Workers, and the Politics of Restructuring. Armonk, New York, London: M.E. Sharpe, 95-112.

CEPAL (2018). Statistics and Indicators. Pozyskano z http://estadisticas.cepal.org/cepalstat/ WEB_CEPALSTAT/estadisticasIndicadores.asp?idioma=i 
DANE (2018). PIB departamental/2000-2016 provisional. Bogota. Pozyskano z https://www. dane.gov.co/files/investigaciones/pib/departamentales/B_2005/PIB_Total_habitante_2016provisional.xlsx.

Deas, M. (2015).The Colombian Conflict: a historical perspective. W: B.M. Bagley, J.D. Rosen (red.). Colombia's Political Economy at the Outset of the Twenty-First Century. Lanham: Lexington Books, 91-109.

Dorocki, S. (2010). Współczesne procesy internacjonalizacji produkcji i delokalizacji przemysłu samochodowego Francji. Prace Komisji Geografii Przemysłu Polskiego Towarzystwa Geograficznego, 16, 125-136.

Dorocki, S. (2018). Changes in the Market of Two and Three-wheeled Motor Vehicles in Europe at the Beginning of the 21st Century. Entrepreneurial Business and Economics Review, 6(1), 175-193. doi.org/10.15678/EBER.2018.060110

Encuesta Anual Manufacturera, 2000-2017 (2018, 13 stycznia). Departamento Administrativo Nacional de Estadística - DANE. Bogota. Pozyskano z http://www.dane.gov.co/index.php/ estadisticas-por-tema/industria/encuesta-anual-manufacturera-enam

Fleet, M. (1982). The politics of automobile industry development in Colombia. Journal of Interamerican Studies and World Affairs, 24(2), 211-239.

Fleet, M. (1984). Bargaining Relations in the Colombian Motor Vehicle Industry. W: R. Kronish, K.S. Mericle (red.). The Political Economy of the Latin American Motor Vehicle Industry. Cambridge Massachusetts - London England: MIT Press, 231-260.

Gawrycki, M.F. (2005). Między wojnq a pokojem - narodowe i międzynarodowe koncepcje rozwiq̨zania konfliktu zbrojnego w Kolumbii. Warszawa: Wydawnictwo Uniwersytetu Warszawskiego.

Informe del sector automotor a diciembre de 2013 (2014). Federación Nacional de Comerciantes - FENALCO. Bogota. Pozyskano z https://www.fenalco.com.co/informesvehiculos/25/42

Informe del sector automotor a diciembre de 2014 (2015). Federación Nacional de Comerciantes - FENALCO. Bogota. Pozyskano z https://www.fenalco.com.co/informesvehiculos/25/42

Jenkins, R.O. (1987). Transnational corporations and the Latin American automobile industry. Pittsburgh: University of Pittsburgh Press.

Kowalewski, Z.M. (1978). Guerrilla latynoamerykańska. Szkice z dziejów rewolucyjnych walk partyzanckich XX wieku. Wrocław: Ossolineum.

Michelsen, O.P. (1979). La industria automotriz en Colombia. Grupo de Trabajo Sobre Economias de Escala en la Industria Automotriz Latinoamericana, Documento Informativo No. 7, CEPAL, Santiago.

Ocampo, J.A., Tovar, C. (2000). Colombia in the Classical Era of 'Inward-Looking Development', 1930-1974. W: E. Cárdenas, J.A. Ocampo, R. Thorp (red.). An Economic History of TwentiethCentury Latin America. Vol. 3: Industrialization and the State in Latin America: The Postwar Years. Houndmills, Basingstoke: Palgrave Macmillan, 205-238.

Presentación Parque Automotor Colombia 2016 (2017). Asociación Colombiana de Vehículos Automotores - ANDEMOS. Bogota. Pozyskano z http://www.andemos.org/wp-content/ uploads/2017/01/Presentacion-Taller-Periodistas-V4.pdf

Rodríguez, H. (2014). ¿El fin de la ensambladora de Mazda? Dinero, Pozyskano z http://www. dinero.com/empresas/articulo/mazda-no-ensamblara-colombia/191801

Safford, F., Palacios, M. (2002). Colombia : fragmented land, divided society. New York-Oxford: Oxford University Press.

Sandoval, D.P., Mick, M., Guterman, L. (1981). Analisis de la trayectoria de una planta automotriz en Colombia: el caso de SOFASA. Programa de Investigaciones sobre Desarrollo Científico y Tecnológico en América Latina, Monografía de Trabajo No. 42, Programa BID/CEPAL/CIID/ PNUD, CEPAL, Buenos Aires.

Sapieżyńska, E. (2016, 17 lipca). Kolumbia: pół wieku wojny i pokój. Krytyka Polityczna. Pozyskano z http://krytykapolityczna.pl/swiat/kolumbia-pol-wieku-wojny-i-pokoj/

Stasiński, M. (2016, 27 września). Rząd Kolumbii i najstarsza partyzantka świata FARC zawarły pokój. Gazeta Wyborcza. Pozyskano z http://wyborcza.pl/1,75399,20753060,rzad-kolumbii-i-najstarsza-partyzantka-swiata-farc-zawarly-pokoj.html 
Transporte en Cifras Estadísticas 2016 (2017). Ministerio de Transporte, Bogota. Pozyskano z https://www.mintransporte.gov.co/documentos/buscar/?q=Transporte+en+Cifras+Estadisticas+

Transporte en Cifras Estadísticas 2017 (2018). Ministerio de Transporte, Bogota. Pozyskano z https://www.mintransporte.gov.co/documentos/buscar/?q=Transporte+en+Cifras+Esadisticas+

UNCTAD (2017). International trade in goods and services. UNCTADSTAT Data Center. Pozyskano $\mathrm{z}$ http://unctadstat.unctad.org/wds/ReportFolders/reportFolders.aspx

Mirosław Wójtowicz, dr nauk o Ziemi w zakresie geografii (specjalność geografia społeczno-ekonomiczna), adiunkt w Katedrze Geografii Społeczno-Ekonomicznej Uniwersytetu Pedagogicznego w Krakowie. Jego zainteresowania badawcze koncentrują się wokół zagadnień procesów urbanizacji oraz industrializacji w Ameryce Łacińskiej, ze szczególnym uwzględnieniem Argentyny, Brazylii i Meksyku.

Mirosław Wójtowicz, PhD in Earth Sciences in the field of Geography (specialisation in Socio-Economic Geography), associate professor in the Department of Socio-Economic Geography at the Pedagogical University of Krakow. His research interests focus on issues of urbanisation and industrialisation process in Latin America, with particular emphasis on Argentina, Brazil and Mexico.

ORCID: 0000-0003-3633-745X

\section{Adres/address:}

Uniwersytet Pedagogiczny w Krakowie

Instytut Geografii

Katedra Geografii Społeczno-Ekonomicznej

ul. Podchorążych 2, 30-084 Kraków, Polska

e-mail: mwojt@up.krakow.pl 